\title{
Calcium Influx via the NMDA Receptor Induces Immediate Early Gene Transcription by a MAP Kinase/ERK-Dependent Mechanism
}

\author{
Zhengui Xia, Henryk Dudek, Cindy K. Miranti, and Michael E. Greenberg \\ Department of Neurology, Division of Neuroscience, Children's Hospital, and Department of Neurobiology, Harvard \\ Medical School, Boston, Massachusetts 02115
}

The regulation of gene expression by neurotransmitters is likely to play a key role in neuroplasticity both during development and in the adult animal. Therefore, it is important to determine the mechanisms of neuronal gene regulation to understand fully the mechanisms of learning, memory, and other long-term adaptive changes in neurons. The neurotransmitter glutamate stimulates rapid and transient induction of many genes, including the c-fos proto-oncogene. The c-fos promoter contains several critical regulatory elements, including the serum response element (SRE), that mediate glutamate-induced transcription in neurons; however, the mechanism by which the SRE functions in neurons has not been defined. In this study, we sought to identify transcription factors that mediate glutamate induction of transcription through the SRE in cortical neurons and to elucidate the mechanism(s) of transcriptional activation by these factors. To facilitate this analysis, we developed an improved calcium phosphate coprecipitation pro- cedure to transiently introduce DNA into primary neurons, both efficiently and consistently. Using this protocol, we demonstrate that the transcription factors serum response factor (SRF) and Elk-1 can mediate glutamate induction of transcription through the SRE in cortical neurons. There are at least two distinct pathways by which glutamate signals through the SRE: an SRF-dependent pathway that can operate in the absence of Elk and an Elk-dependent pathway. Activation of the Elkdependent pathway of transcription seems to require phosphorylation of Elk-1 by extracellular signal-regulated kinases (ERKs), providing evidence for a physiological function of ERKs in glutamate signaling in neurons. Taken together, these findings suggest that SRF, Elk, and ERKs may have important roles in neuroplasticity.

Key words: transfection; neurons; transcription, c-fos; glutamate; MAP kinase; ERK; SRF; Elk
Glutamate is the major excitatory neurotransmitter in the mammalian brain and regulates activity-dependent changes in neuronal function both during development and in the mature nervous system. Two classes of glutamate receptors are expressed on the neuronal cell surface: the ionotropic receptors, which mediate ion influxes, and the G-protein-coupled metabotropic receptors (Nakanishi, 1992; Seeburg, 1993). NMDA receptors are ionotropic glutamate receptors that, when activated, mediate calcium influx. There is considerable evidence that NMDA receptors are critical mediators of activity-dependent synaptic changes (Kleinschmidt et al., 1987; Fox et al., 1991; Madison et al., 1991; Rabacchi et al., 1992). A well characterized example of this is NMDA-dependent long-term potentiation (LTP) in the neocortex (Kirkwood et al., 1993) and hippocampus (Jahr and Lester, 1992; Bliss and Collingridge, 1993; Malenka, 1994).

\footnotetext{
Received Jan. 31, 1996; revised June 6, 1996; accepted June 18, 1996.

This work was supported by National Institutes of Health (NIH) Grant NS28829, American Cancer Society Faculty Research Award FRA-379 (M.E.G.), by Mental Retardation Research Center Grant NIH P30-HD 18655, by Massachusetts Medica Foundation Post-Doctoral Fellowship RF 78780-01 (Z.X.), by National Institutes of Health Post-Doctoral Training Grant NS 07009-2021 (Z.X.), and by American Cancer Society Post-Doctoral Fellowship PF-4059 (H.D.). We thank Drs. R. Treisman, C. Hill, H. Sun, and N. K. Tonks for generously supplying some of the plasmids used in this study, Dr. Richard Vallee for providing the antibody to MAP-2, Susan Kim for technical support, and members of the Greenberg Laboratory for critical reading of this manuscript.

The first two authors contributed equally to this work.

Correspondence should be addressed to Dr. Michael E. Greenberg, Division of Neuroscience, Enders, Room 250, Children's Hospital, 300 Longwood Avenue, Boston, MA 02115.

Dr. Miranti's present address: ARIAD Pharmaceuticals, 26 Lansdowne, Cambridge, MA 02139.

Copyright (C) 1996 Society for Neuroscience $0270-6474 / 96 / 165425-12 \$ 05.00 / 0$
}

LTP is an activity-dependent enhancement of synaptic efficacy that can last for hours or days in intact animals (Bliss and Lømo, 1973; Jahr and Lester, 1992; Bliss and Collingridge, 1993; Bear and Malenka, 1994; Malenka, 1994). Classical LTP in the CA1 region of the hippocampus (E-LTP) persists for only a few hours and is independent of new protein synthesis. In contrast, longlasting LTP in the CA1 (L-LTP), which is produced by multiple trains of high-frequency stimuli, lasts for hours or even days and requires de novo transcription and protein synthesis (Grecksch and Matthies, 1980; Mathies et al., 1990; Huang et al., 1994; Nguyen et al., 1994). LTP may be a useful model for studying molecular mechanisms that contribute to learning and memory and to experience-dependent synaptic plasticity in the visual cortex (Grant et al., 1992; Silva et al., 1992; Kirkwood et al., 1995; Wu et al., 1995). Like LTP, learning has two distinct components: a short-term form, which is independent of mRNA synthesis, and a long-lasting form, which is mRNA- and protein synthesisdependent (Grecksch and Matthies, 1980; Montarolo et al., 1986; Yin et al., 1994). Given the importance of new gene expression for both LTP and learning, it is critical to elucidate the mechanisms by which glutamate regulates transcription in neurons.

Several studies have identified genes that are induced by LTP paradigms as well as by glutamate. These genes include c-fos and zif268 (also termed NGFIA/Egr-1/Krox24) (Cole et al., 1989; Dragunow et al., 1989; Jeffery et al., 1990; Bading et al., 1993; Lerea and McNamara, 1993; Worley et al., 1993; Williams et al., 1995); however, the mechanisms by which glutamate regulates these genes in neurons are largely undefined. In other cell culture systems, the c-fos gene has proved to be a useful model for 
defining the signaling pathways by which extracellular stimuli trigger changes in gene expression (Sheng and Greenberg, 1990; Ginty et al., 1992; Ghosh and Greenberg, 1995; Treisman, 1995). Within the promoter of the c-fos gene, several regulatory elements have been defined that are important for the c-fos transcriptional response. These include the serum response element (SRE) and the calcium/cyclic AMP response element (CRE/CaRE) that are located approximately 310 nucleotides (SRE) and 60 nucleotides (CRE) 5' of the initiation site of c-fos mRNA synthesis (Deschamps et al., 1985; Treisman, 1985; Gilman et al., 1986; Sheng et al., 1988; Rivera and Greenberg, 1990). In vitro binding studies have shown that the SRE can interact with many transcription factors, including the serum response factor (SRF), which binds to the SRE as a homodimer (Gilman et al., 1986; Prywes and Roeder, 1986; Treisman, 1986; Greenberg et al., 1987; Norman et al., 1988), the ternary complex factor (TCF) (Treisman, 1994), NF-IL 6, YY-1, and Phox1 (Treisman, 1992). TCFs are a family of Ets-domain containing transcription factors that include Elk-1, Sap-1a, Sap-1b, and Sap-2/Net/ERP (Rao et al., 1989; Shaw et al., 1989; Hipskind et al., 1991; Dalton and Treisman, 1992; Giovane et al., 1994). TCFs interact with the c-fos SRE only when SRF is already bound, thereby forming a ternary complex composed of an SRF dimer and a single molecule of TCF (Mueller and Nordheim, 1991; Shaw, 1992; Treisman, 1992). Studies using fibroblasts and PC12 cells have revealed that phosphorylation of the TCF Elk-1 at its $\mathrm{C}$ terminus is critical for its ability to stimulate transcription in response to serum or growth factor addition (Gille et al., 1992; Janknecht et al., 1993; Marais et al., 1993; Hipskind et al., 1994; Gille et al., 1995; Miranti et al., 1995; Price et al., 1995). The phosphorylation of Elk-1 that occurs on growth factor stimulation seems to be catalyzed by members of the microtubule-associated protein (MAP) kinase family, the extracellular signal-regulated kinases (ERKs).

Recent studies have shown that the SRE can mediate glutamate induction of c-fos transcription in hippocampal neurons (Bading et al., 1993); however, the mechanisms by which glutamate regulates SRE-mediated transcription in neurons had not been characterized. It was not known which of the many transcription factors that can bind to the SRE in vitro are involved in glutamate regulation of c-fos expression. For example, are SRF or TCFs critical for the c-fos response? If TCFs are found to be important, it will be useful to know which of the TCF family members are involved. In addition, it will be worthwhile to define the signal transduction pathways that lead to the activation of the SRE bound transcription factors. Although the ERKs are activated by glutamate treatment in cultured hippocampal and cortical neurons (Bading and Greenberg, 1991; Fiore et al., 1993a,b) (L. Rosen, S. Finkbeiner, and M. E. Greenberg, unpublished observations), whether these enzymes play a role in transmitting the glutamate signal to the nucleus is unknown. On the basis of the results of studies of c-fos transcription in non-neuronal cells, we hypothesized that glutamate stimulation leads to ERK activation and that ERKs then catalyze the phosphorylation of Elk-1 and the activation of c-fos transcription. In the present study, we provide evidence in support of this hypothesis.

\section{MATERIALS AND METHODS}

Plasmids. The expression vectors for SRF (pMLV.SRF.M2), Elk-1 (pMLV.NL.Elk-1), and Elk-1 mutant pMLV.NL.Elk-1(383/389), and the reporter plasmid pF4, were obtained from Dr. R. Treisman (Treisman, 1985; Hill et al., 1993). The expression vector for the MAP kinase phosphatase pSG5.MKP-1 was obtained from Drs. H. Sun and N. K. Tonks (Sun et al., 1993). The following constructs have been described previously: $\mathrm{pSV} \alpha 1$
(Shyu et al., 1989), pAF42.SRE.WT and pAF42.SRE.mut2 (Rivera et al., 1990), pAF42.SRE.pm1 and pAF42.SRE.mut6 (Misra et al., 1994), pAF42.SRE.M2, pAF42.SRE.LM2 (Hill et al., 1993; Miranti et al., 1995), and pON260 (Cherrington and Mocarski, 1989).

Cell culture. Neurons were grown in several different media, all of which were compatible with calcium phosphate transfection. Hippocampal neurons shown in Figure 2 were cultured from newborn (P0) rats as described previously (Bading et al., 1993). Cortical neurons from P0 rats were grown in growth media based on either DMEM (Life Technologies, Gaithersburg, MD) or basal medium Eagle (BME) (Sigma, St. Louis, MO). Cortical neurons from embryonic day 17/18 (E17/E18) rats were grown in BME growth medium. The DMEM growth medium was composed of DMEM supplemented with $1 \mathrm{~mm}$ glutamine (Sigma), $5 \%$ rat serum (Harlan, Indianapolis, IN), $100 \mathrm{U} / \mathrm{ml}$ penicillin, and $0.1 \mathrm{mg} / \mathrm{ml}$ streptomycin (Sigma). The BME growth medium was composed of (per $100 \mathrm{ml}) 91 \mathrm{ml}$ of BME, $5 \mathrm{ml}$ of calf serum (Hyclone, Logan, UT), $1.4 \mathrm{ml}$ of $2.5 \mathrm{M}$ glucose ( $35 \mathrm{~mm}$ final), $0.5 \mathrm{ml}$ of $0.2 \mathrm{M}$ L-glutamine ( $1 \mathrm{~mm}$ final), $0.5 \mathrm{ml}$ of penicillin/streptomycin (Sigma), $0.45 \mathrm{ml}$ of Stable Vitamin Mix ( $3 \mathrm{mg} / \mathrm{ml} \mathrm{L}$-proline, $3 \mathrm{mg} / \mathrm{ml}$ L-cystine, $1 \mathrm{mg} / \mathrm{ml} p$-aminobenzoic acid, 0.4 $\mathrm{mg} / \mathrm{ml}$ vitamin B-12, $2 \mathrm{mg} / \mathrm{ml}$ myo-inositol, $2 \mathrm{mg} / \mathrm{ml}$ choline chloride, 5 $\mathrm{mg} / \mathrm{ml}$ fumaric acid, $80 \mu \mathrm{g} / \mathrm{ml}$ coenzyme A, $0.4 \mu \mathrm{g} / \mathrm{ml}$ D-biotin, $0.1 \mathrm{mg} / \mathrm{ml}$ DL-6,8,-thioctic acid), $50 \mu \mathrm{l}$ of ITS $(5 \mathrm{mg} / \mathrm{ml}$ insulin, $5 \mathrm{mg} / \mathrm{ml}$ human transferrin, $5 \mu \mathrm{g} / \mathrm{ml}$ sodium selenite; Sigma), $0.5 \mathrm{ml}$ of $1.6 \mathrm{mg} / \mathrm{ml} \mathrm{pu}-$ trescine (Sigma), $0.5 \mathrm{ml}$ of $5 \mathrm{mg} / \mathrm{ml}$ transferrin (Sigma), and $12 \mu \mathrm{l}$ of $1 \mathrm{~mm}$ progesterone. The cells were seeded into 24 -well plates on glass coverslips (Bellco) at a density of $2 \times 10^{5}$ cells/well (for Fig. $1 B-F$ ) or $3 \times 10^{6}$ cells/60-mm-diameter dish, and maintained in a humidified incubator with $5 \% \mathrm{CO}_{2}$ at $37^{\circ} \mathrm{C}$. Plates and coverslips were coated with polylysine and laminin (Collaborative Biomedical Product, Bedford, MA). Cytosine- $\beta$-D-arabinofuranoside (Ara-C, $2.5 \mu \mathrm{M}$ ) was added to P0 cultures on the second day after seeding (2 DIV).

Calcium phosphate transfection of neurons. We took a number of steps to minimize neurotoxicity and maximize transfection efficiency. Potential toxicity was assessed by examining cells for morphological degeneration or nuclear fragmentation (using the DNA dye Hoechst 33258; Sigma). Transfection efficiency was assessed by determining either the percentage of cells expressing $\beta$-galactosidase (after staining cells with the substrate $\mathrm{X}$-gal, 5-bromo-4-chloro-3-indolyl- $\beta$-gal) or the amount of $\alpha$-globin RNA transcribed (using RNase protection analysis). One step taken to reduce toxicity was the inclusion in the transfection medium of kynurenate and $\mathrm{MgCl}_{2}$, inhibitors of ionotropic glutamate receptors (both NMDA and non-NMDA types) and NMDA receptors, respectively. The addition of these inhibitors decreased neurotoxicity when cortical neurons from P0 rats were transfected $3 \mathrm{~d}$ after seeding ( $3 \mathrm{DIV}$ ) or later. For the transfections shown in Figure 1, D(-)-2-amino-5-phosphonovaleric acid (APV), a specific NMDA receptor antagonist, was added to the culture medium after transfection to reduce toxicity. This should be useful for studies not involving signaling through NMDA receptors. We found that a critical variable for successful transfection is the amount of calcium phosphate/DNA precipitate added per plate and the duration of exposure of the neurons to the precipitate. The optimum volume of the calcium phosphate/DNA precipitate was $120 \mu \mathrm{l} / 60$-mm-diameter dish; larger volumes increased toxicity. The duration of the incubation with DNA/ calcium phosphate precipitate was dictated by how fast the precipitate was formed on the plate. Typically, 30-45 min were required for the layer of precipitate to form on the plates, and the incubation was stopped 20-25 min later. Longer exposures to DNA/calcium phosphate precipitate caused toxicity. Another important factor for improved transfection efficiency was a $2 \%$ DMSO or $5 \%$ glycerol "osmotic shock" at the end of the incubation with the calcium phosphate/DNA precipitate. The $2 \%$ DMSO shock did not increase transfection efficiency, but it reduced variability between transfections without increasing toxicity. The 5\% glycerol shock consistently increased transfection efficiency, but caused some toxicity if P0 cortical neurons were transfected after 5 DIV. In addition to these factors, the $\mathrm{pH}$ of the HEPES buffered saline (HBS) was critical. The optimum $\mathrm{pH}$ for the $2 \times \mathrm{HBS}$ was 7.07 , although it is advisable to check several different $\mathrm{pH}$ values.

Using these optimized conditions, cortical or hippocampal neurons from P0 rats were transfected on 3 DIV (third day after seeding). The conditioned culture media were removed and saved. The cells were incubated in $3-5 \% \mathrm{CO}_{2}$ for $1 \mathrm{hr}$ with $3 \mathrm{ml}$ of fresh DMEM (per 60-mm-diameter plate) supplemented with $1 \mathrm{~mm}$ sodium kynurenate/10 $\mathrm{mm} \mathrm{MgCl}_{2}$ in $5 \mathrm{~mm}$ HEPES, $\mathrm{pH}$ 7.5. During this time, the DNA/calcium phosphate precipitate was prepared by mixing one volume of DNA in 250 $\mathrm{mM} \mathrm{CaCl}_{2}$ with an equal volume of $2 \times \mathrm{HBS}(274 \mathrm{~mm} \mathrm{NaCl}, 10 \mathrm{mM} \mathrm{KCl}$, 
$1.4 \mathrm{~mm} \mathrm{Na} \mathrm{HPO}_{4}, 15 \mathrm{~mm}$ D-glucose, $42 \mathrm{~mm}$ HEPES, pH 7.07). The precipitate was allowed to form for $25-30 \mathrm{~min}$ at room temperature before addition to the cultures. Six to eight micrograms of total plasmid DNA were used for each 60-mm-diameter plate. In a typical experiment, the following amounts of plasmid were used: $1 \mu \mathrm{g}$ reporter plasmid, 200-300 ng of expression vectors for SRF or Elk-1, $3 \mu \mathrm{g}$ of the SV40 promoter-driven human $\alpha$-globin gene, $4 \mu \mathrm{g}$ of the expression vector for the MAP kinase phosphatase MKP-1 or its empty cloning vector pSG5, and carrier plasmid DNA, e.g., pUC19, whenever necessary to maintain a constant amount of DNA per dish. One hundred and twenty microliters of the DNA/calcium phosphate precipitate were added drop-wise to each 60-mm-diameter dish and mixed gently. Plates were then returned to the $3-5 \% \mathrm{CO}_{2}$ incubator. The incubation was stopped $20-25 \mathrm{~min}$ after the layer of precipitate first formed on the plates by "shocking" the cells for 1-2 min with $1 \times \mathrm{HBS} / 1 \mathrm{~mm}$ sodium kynurenate and $10 \mathrm{mM} \mathrm{MgCl}_{2}$ in 5 mM HEPES, pH 7.5/2\% DMSO or $5 \%$ glycerol. Cells were then washed three times with $3 \mathrm{ml}$ of DMEM. The saved conditioned medium was added back to each plate, and the cells were returned to the $5 \% \mathrm{CO}_{2}$ incubator at $37^{\circ} \mathrm{C}$.

A similar transfection protocol was followed for E17/18 cortical neurons growing in 24-well plates (Fig. $1 B, C$ ), with the following modifications: cultures were transfected on 3 or 4 DIV using $20 \mu \mathrm{l}$ of DNA/ calcium phosphate precipitate containing 1-2 $\mu \mathrm{g}$ plasmid DNA per well. Twenty to twenty-five min after the layer of precipitate first formed on the plates, cells were washed two times with $0.5 \mathrm{ml}$ DMEM containing $1 \mathrm{mM}$ sodium kynurenate and $10 \mathrm{mM} \mathrm{MgCl}_{2}$ without the "osmotic shock." The conditioned culture medium supplemented with $100 \mu \mathrm{M}$ APV was added back, and the cells were returned to the $5 \% \mathrm{CO}_{2}$ incubator at $37^{\circ} \mathrm{C}$.

Cell staining. Cells were stained on 6 DIV or 2-3 d after transfection. Expression of $\beta$-galactosidase was detected either with the substrate $\mathrm{X}$-gal or by immunostaining with a mouse monoclonal antibody to $\beta$-galactosidase (1:300 dilution; Promega, Madison, WI) and fluoresceinconjugated goat antibody to mouse immunoglobulin (IgG). To visualize the nuclei of transfected cells, we included the DNA dye Hoechst 33258 $(2.5 \mu \mathrm{g} / \mathrm{ml}$; Sigma) in the wash after the secondary antibody incubation. To identify neurons in culture, the expression of the neuronal marker protein MAP-2 was detected by immunostaining with a rabbit polyclonal antibody to MAP-2 (1:2000 dilution; a gift from Dr. R. Vallee) and Texas Red-conjugated goat antibody to rabbit IgG (Fig. 1B), or biotinylated goat antibody to rabbit IgG and the avidin/biotin/peroxidase detection system (Vector Laboratories, Burlingame, CA) (Fig. 3A). Immunocytochemistry with antibodies to cyclic AMP regulatory element binding protein (CREB) (anti-N-CREB) or CREB phosphorylated at serine residue 133 (anti-P-CREB) was performed as described (Ginty et al., 1993).

Cell stimulation. Cultures were stimulated as described but with the following modifications (Bading et al., 1993). Cells were treated with glutamate, NMDA, or membrane depolarization on 6 DIV for cortical neurons, or on 5 or 8 DIV for hippocampal neurons. Tetrodotoxin $(1 \mu \mathrm{M})$ and CNQX $(40 \mu \mathrm{M})$ were added to all plates the night before stimulation to reduce endogenous synaptic activity. Control stimulated cultures were pretreated for $30 \mathrm{~min}$ with both $100 \mu \mathrm{M}$ APV and $5 \mu \mathrm{M}$ nimodipine. Cells stimulated with glutamate or NMDA were pretreated for 30 min with 5 $\mu \mathrm{M}$ nimodipine. Cells exposed to a membrane-depolarizing concentration of $\mathrm{KCl}(55 \mathrm{mM})$ were pretreated for $30 \mathrm{~min}$ with $100 \mu \mathrm{M}$ APV. For Western blotting analysis, cells were then stimulated for $10 \mathrm{~min}$ with 10 $\mu \mathrm{M}$ glutamate, and cell extracts were prepared in boiling SDS sample buffer. For RNase protection analysis, cells were stimulated with $10 \mu \mathrm{M}$ glutamate, $100 \mu \mathrm{M}$ NMDA, or $55 \mathrm{mM} \mathrm{KCl}$, and total RNA was collected $50 \mathrm{~min}$ after stimulation. To prevent excitotoxic cell death, $1 \mathrm{~mm}$ sodium kynurenate and $10 \mathrm{mM} \mathrm{MgCl}_{2}$ were added to the medium $10 \mathrm{~min}$ after the addition of glutamate, NMDA, or $\mathrm{KCl}$.

$R N A$ isolation, RNase protection analysis, and quantitation. RNA was isolated and RNase protections were performed as described (Chomczynski and Sacchi, 1987; Sheng et al., 1988). Because there is little or no expression of the transfected fos ${ }^{\mathrm{h}}$ reporter constructs in unstimulated cells, the fold induction of transcription after glutamate treatment cannot be calculated. Therefore, the expression level of the $\operatorname{fos}^{\mathrm{h}}$ mRNA relative to that of the globin mRNA was used for quantitation. The level of transcription from each reporter construct was determined by dividing the signal intensity of the fos ${ }^{\mathrm{h}}$ band, obtained using a PhosphorImager, over that of the globin band (fos $/$ globin). The relative levels of transcription between different reporter constructs after glutamate treatment were determined by this ratio (fos $/$ globin).

\section{RESULTS}

\section{Transfection of primary neurons using a modified calcium phosphate method}

Studies of the mechanisms controlling gene expression in neurons have been limited because of difficulties encountered when attempting to transfect postmitotic neurons. To explore mechanisms by which glutamate regulates transcription in neurons, it was necessary to develop a method for reliably and efficiently introducing DNA into neurons with minimal toxicity. Although there have been a few studies describing transfection of cultured neurons by the calcium phosphate method (Korner et al., 1989; Werner et al., 1990; Gabellini et al., 1992; Blochl and Thoenen, 1995), this method has not been used extensively because of its toxicity for neurons. We have developed a modified calcium phosphate transfection method applicable for the transient transfection of CNS neurons in primary culture. We have accomplished nontoxic transfection of neurons at relatively high efficiency by optimizing several experimental parameters. These include the amount of calcium phosphate DNA precipitate added per plate, the duration of exposure of neurons to the calcium phosphate/ DNA precipitate, the inclusion of inhibitors of glutamate receptors, and an osmotic shock of the neurons at the end of the incubation with the calcium phosphate/DNA precipitate (for details, see Materials and Methods).

Using this method, rat cortical neurons were transfected with a plasmid encoding $\beta$-galactosidase, pON260, and $2 \mathrm{~d}$ later cells were stained with $\mathrm{X}$-Gal, a $\beta$-galactosidase substrate. Numerous transfected cells were readily detectable (Fig. 1A); the transfection efficiency in these experiments was $\sim 2 \%$. To confirm that the transfected cells were neurons, we performed doubleimmunofluorescence staining for $\beta$-galactosidase and the neuronspecific marker protein MAP-2 (Fig. $1 B$ ). More than $90 \%$ of the transfected cells stained positive for MAP-2 (Fig. $1 B$ ), consistent with the low abundance of non-neuronal cells in these cultures (see also Fig. 3). The morphology of the transfected neurons, including the presence of phase-bright cell bodies and long processes, indicated that they remained healthy after transfection. In addition, staining of transfected neurons with the DNA dye Hoechst 33258 revealed that $\sim 90 \%$ of the transfected cells showed an evenly stained, nonfragmented, and noncondensed nuclear morphology (Fig. 1C), suggesting that these transfected cells were healthy. Thus, this transfection method allows efficient and nontoxic DNA transfection of cultured neurons.

It was important to determine whether genes introduced into neurons by this method are regulated correctly in response to extracellular stimuli. To address this question, plasmid $\mathrm{pF} 4$, which contains a $5.4 \mathrm{~kb}$ fragment of the intact human c-fos gene including $750 \mathrm{bp}$ of $5^{\prime}$ regulatory sequence (Treisman, 1985), was transfected into cortical neurons. A plasmid that directs the constitutive expression of human $\alpha$-globin gene was cotransfected with $\mathrm{pF} 4$ and serves as an internal control for variations in transfection efficiency and RNA recovery between samples. The transfected cells were stimulated by exposure to either $55 \mathrm{~mm}$ $\mathrm{KCl}$, which depolarizes the membrane and stimulates $\mathrm{Ca}^{2+}$ influx through voltage-sensitive $\mathrm{Ca}^{2+}$ channels (VSCCs) (Tsien et al., 1988; Bean, 1989), or $10 \mu \mathrm{M}$ glutamate, which stimulates $\mathrm{Ca}^{2+}$ influx through NMDA receptors. When cells were stimulated with $55 \mathrm{~mm} \mathrm{KCl,} \mathrm{APV} \mathrm{(an} \mathrm{NMDA-receptor} \mathrm{antagonist)} \mathrm{and} \mathrm{CNQX}$ (an inhibitor of non-NMDA ionotropic glutamate receptors) were included in the stimulation media to minimize the activation of glutamate receptors. To minimize activation of non-NMDA iono- 

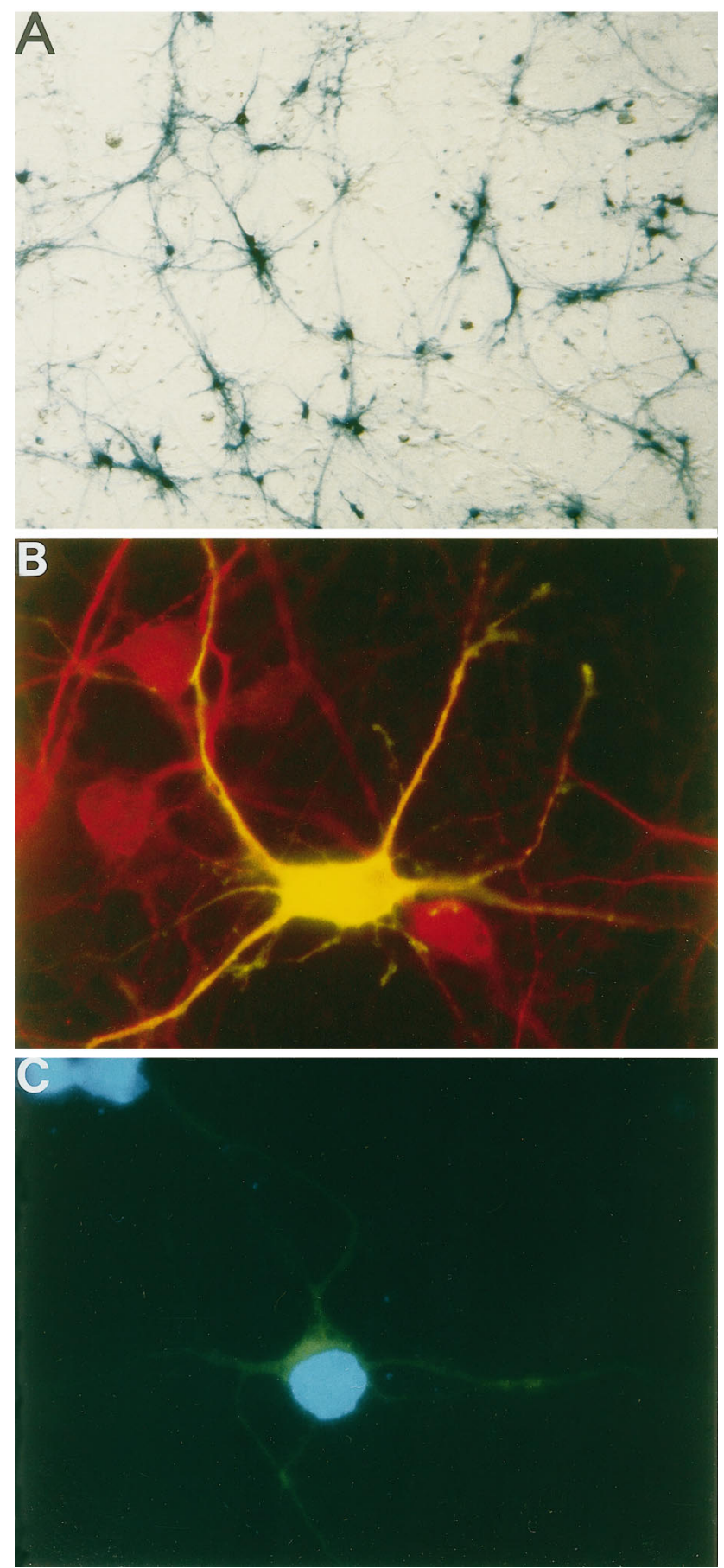

Figure 1. Transient transfection of the $\beta$-galactosidase gene into primary cortical neurons using a modified calcium phosphate procedure. $A$, X-Gal staining (blue) of cortical neurons (P0) transfected at 3 DIV with an expression vector encoding $\beta$-galactosidase. $B$, A representative immunofluorescence photomicrograph of a neuron transfected with $\beta$-galactosidase. Transfected cortical neurons cultured from E17/18 rats were detected by immunostaining with a monoclonal antibody to $\beta$-galactosidase, visualized by fluorescein-conjugated goat antibody to mouse IgG (green). The cells were coimmunostained for the neuronal marker protein MAP-2, which was visualized using a Texas Red-conjugated goat antibody to rabbit IgG (red ). The transfected neuron appears yellow because of the colocalization of green staining from anti- $\beta$-galactosidase and red staining from anti-MAP-2. $C, \mathrm{~A}$ representative immunofluorescence photomicrograph of a healthy neuron expressing $\beta$-galactosidase. A transfected E17/18 rat cortical neuron was detected as in $B$. The nucleus was visualized using the DNA dye Hoechst 33258 (blue). The evenly stained, round morphology is typical of a healthy (nonapoptotic) nucleus.

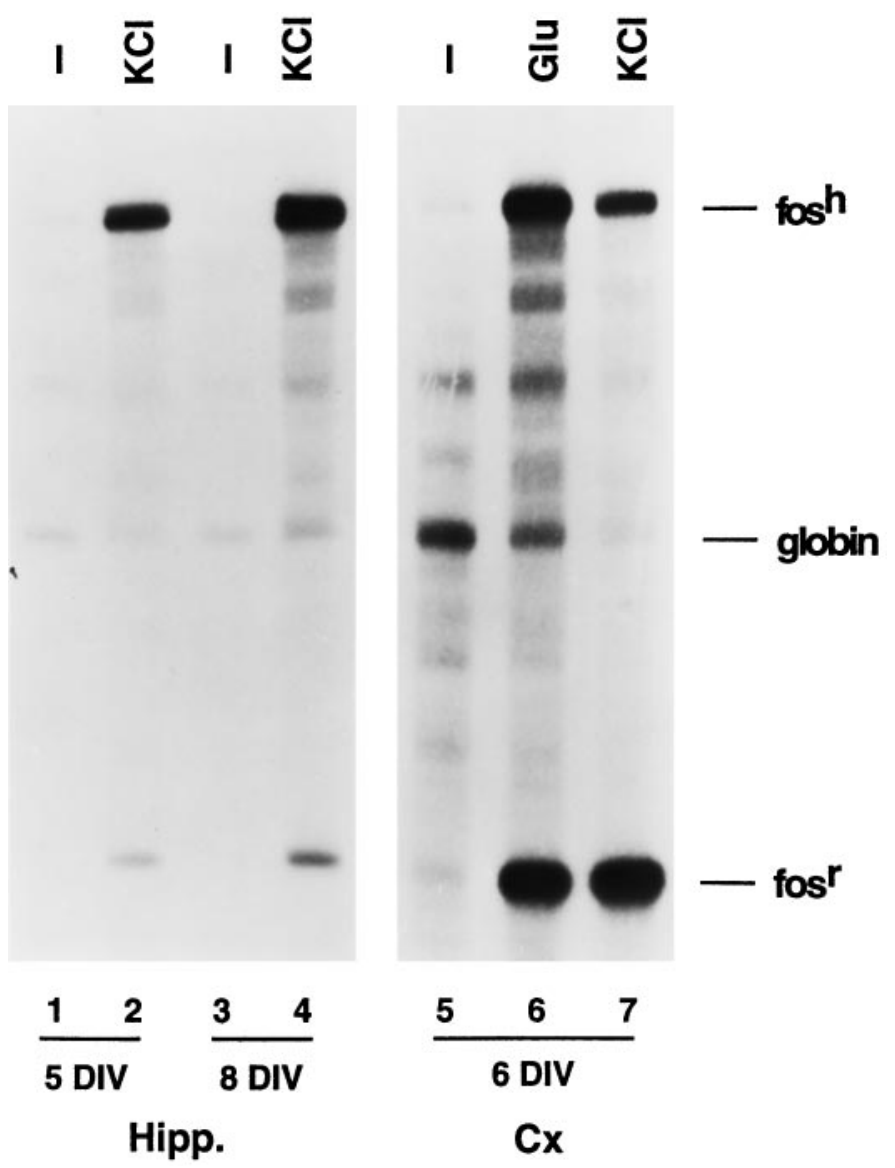

Figure 2. Genes transfected into neurons are correctly regulated in response to extracellular stimuli. The plasmid $\mathrm{pF} 4$, which contains the intact human c-fos gene including $750 \mathrm{bp}$ of $5^{\prime}$ regulatory sequence, was transfected $3 \mathrm{~d}$ after plating ( $3 \mathrm{DIV}$ ) into hippocampal (Hipp., lanes $1-4)$ or cortical neurons $(C x$, lanes $5-7)$. The plasmid $\mathrm{pSV} \alpha 1$, which encodes the human $\alpha$-globin gene under the control of the SV40 promoter, was cotransfected as an internal control for transfection efficiency and RNA recovery ( $2 \mu \mathrm{g} /$ plate). For hippocampal neurons, $0.9 \times 10^{6}$ cells were plated onto each 60 -mm-diameter plate, and $5 \mu \mathrm{g}$ of $\mathrm{pF} 4$ plasmid DNA was used for transfection. For cortical neurons, $3 \times 10^{6}$ cells were plated onto each 60 -mm-diameter plate, and $4 \mu \mathrm{g}$ of $\mathrm{pF} 4$ plasmid DNA was used for transfection. Transfected cells were either left untreated $(-)$ or stimulated with $55 \mathrm{~mm} \mathrm{KCl}$ or $10 \mu \mathrm{M}$ glutamate (Glu) on 5 DIV (lanes 1 and 2), 6 DIV (lanes 5-7), or 8 DIV (lanes 3 and 4 ). RNase protection analysis was used to measure the expression of the transfected human c-fos gene (fos $\left.{ }^{\mathrm{h}}\right)$, the human $\alpha$-globin gene, and the endogenous rat c-fos gene $\left(\right.$ fos $\left.^{\mathrm{r}}\right)$.

tropic glutamate receptors and the opening of VSCCs, CNQX and nimodipine (an antagonist of VSCCs) were included in the media when cells were stimulated with glutamate. In each experiment, the levels of expression of the transfected human c-fos gene $\left(f \circ s^{\mathrm{h}}\right)$, the endogenous rat c-fos gene (fos ${ }^{\mathrm{r}}$ ), and the transfected $\alpha$-globin gene were determined using an RNase protection assay (Sheng et al., 1988). The correctly initiated and spliced human c-fos gene transcript protects a 296-nucleotide fragment of the c-fos probe, whereas the endogenous rat c-fos mRNA protects a 65 -nucleotide fragment. The correctly initiated human $\alpha$-globin gene transcript protects a 133-nucleotide fragment of the globin probe. In addition to these three major bands, another band is observed between fos ${ }^{\mathrm{h}}$ and globin. This 190-nucleotide band is present when RNase protection assays are performed using mRNA from cells transfected with the $\alpha$-globin gene in the 


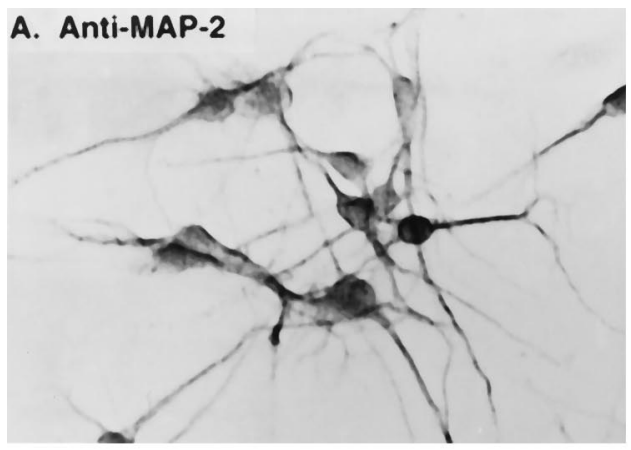

B. Anti-N-CREB

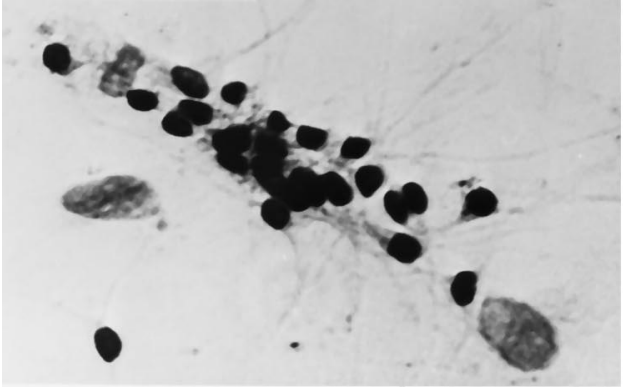

C. Glut. /anti-P-CREB

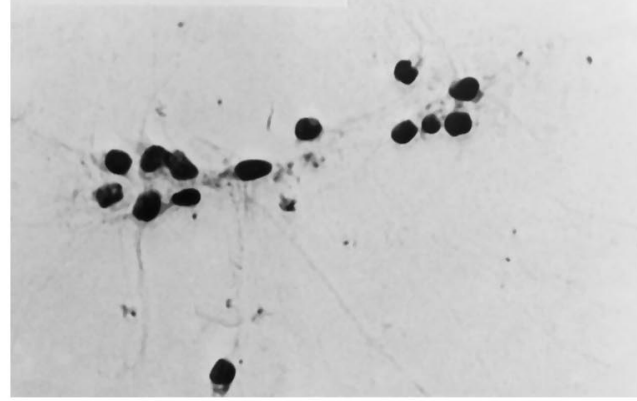

D. Glut. + APV/anti-P-CREB

f

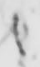

Figure 3. Glutamate responsiveness of cultured cortical neurons. Cortical neurons were immunostained with an antibody to the neuronal marker protein MAP-2 $(A)$, an antibody to the N terminus of CREB $(B)$, or an antibody specific for CREB that is phosphorylated at serine $^{133}(C, D)$. Cells were unstimulated $(A, B)$, or stimulated for 10 min with 10 $\mu \mathrm{M}$ glutamate in the absence $(C)$ or presence $(D)$ of $100 \mu \mathrm{M}$ APV. Glutamate induced CREB phosphorylation only in cells with neuronal morphology. absence of the human c-fos gene (S. Finkbeiner and M. E. Greenberg, unpublished data). Therefore, the band may be derived from $\alpha$-globin mRNA expressed from the transfected human globin gene, and most likely reflects either partial digestion of the globin probe or incorrect initiation or splicing of the human globin gene transcript in these neurons.

The correctly initiated $\mathrm{pF} 4$ message, like the endogenous c-fos mRNA, was found to be induced by either $\mathrm{KCl}$ or glutamate treatment of transfected hippocampal or cortical neurons (Fig. 2 and data not shown). A consistently high level of $c-f_{0}{ }^{h}$ mRNA was synthesized on stimulation from the exogenously introduced c-fos gene, even when the time period between the initial transfection and the stimulation was varied between 1 and $5 \mathrm{~d}$. Taken together, these data suggest that the c-fos gene transfected into neurons by the calcium phosphate precipitation method is regulated correctly in response to extracellular stimuli in different cell types and at a range of times after transfection.

\section{Intact binding sites for SRF and TCFs within the SRE are required for a full transcriptional response to glutamate}

An objective of the present study was to identify specific transcription factors that mediate glutamate induction of c-fos transcription in neurons. To address this issue, we have used primary cortical neurons cultured from P0 rats. More than $90 \%$ of the cells in our culture preparation were neurons, as indicated by positive staining with an antibody that recognizes MAP-2 (Fig. $3 A$ ). The MAP-2-positive neurons have small round cell bodies and an extensive array of neurites, whereas the MAP-2-negative nonneuronal cells have large flat cell bodies and few processes. To confirm that the transcriptional response to glutamate in these cultures occurs in neurons, we determined whether the cell types that were responsive to glutamate stimulation were neurons or glia. This was achieved by monitoring the phosphorylation of a transcription factor, CREB, before and $10 \mathrm{~min}$ after glutamate treatment. We have previously generated an antibody that specifically recognizes CREB when it is phosphorylated at serine ${ }^{133}$
(anti-P-CREB), and demonstrated that CREB undergoes specific phosphorylation at amino acid residue serine ${ }^{133}$ when hippocampal or cortical neurons are exposed to glutamate (Ginty et al., 1993). Immunohistochemical analysis using the anti-P-CREB antibody demonstrated that glutamate treatment induced phosphorylation of CREB at serine ${ }^{133}$ in $>90 \%$ of the cells in our cortical cultures within 10 min (Fig. $3 C$ ). By contrast, in unstimulated cultures, very few cells stained positive with the anti-P-CREB antibody (data not shown). The P-CREB-positive cells in the glutamate-stimulated cultures displayed a neuronal morphology (Fig. 3C). Glutamate induction of CREB phosphorylation required the activation of NMDA receptors, because the phosphorylated form of CREB was not detected when cells were pretreated with APV before glutamate addition (Fig. 3D). The failure to detect significant amounts of serine ${ }^{133}$-phosphorylated CREB in non-neuronal cells was not attributable to the absence of CREB in these cells, because all of the cells in the culture stained positive when an antibody that recognizes CREB regardless of its phosphorylation state (anti-N-CREB) was used (Fig. 3B). Taken together, these results suggest that in primary cortical cultures, it is the neurons, not the glia, that are directly responsive to glutamate stimulation.

To begin to identify the specific transcription factors that mediate glutamate induction of c-fos transcription, we introduced various mutations into the SRE that are known to interfere with the binding of specific transcription factors. Human c-fos reporter genes bearing these mutations were introduced into cortical neurons, and the effects of the mutations on glutamate-stimulated c-fos mRNA expression were analyzed. The plasmid pAF42.SRE.wt contains a single copy of the wild-type c-fos SRE inserted $42 \mathrm{bp} 5^{\prime}$ of the transcription initiation site in the plasmid pAF42. pAF42 contains a copy of the human c-fos gene in which the promoter has been deleted of all known transcription regulatory sequences $5^{\prime}$ of the TATAA box (Rivera et al., 1990). Three days after cortical cultures were transfected with pAF42.SRE.wt, they were stimulated with glutamate in the presence of nimodipine and CNQX. 


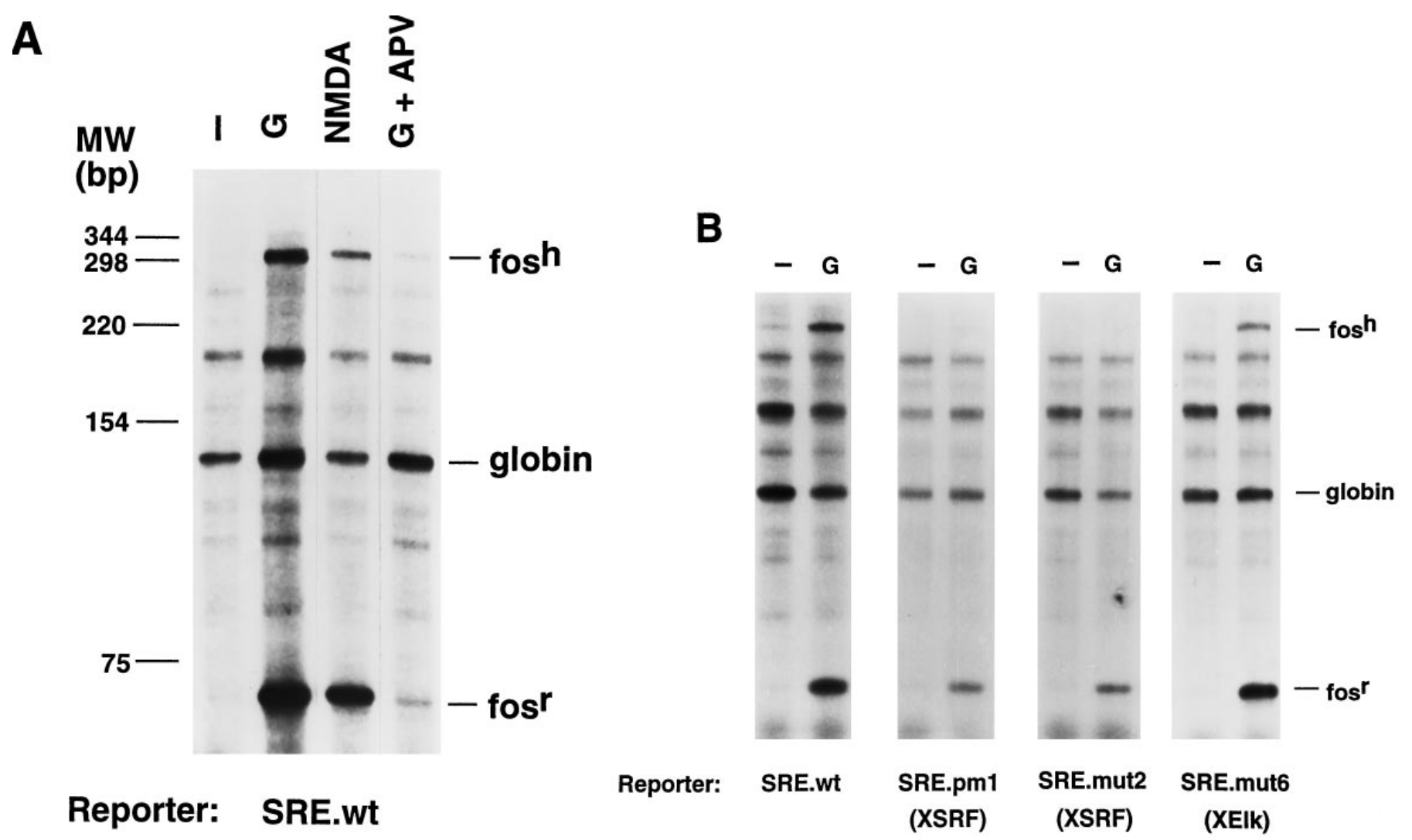

Figure 4. Contribution of the SRF and TCF binding sites for glutamate stimulation of SRE-mediated transcription. $A$, Glutamate stimulation of SRE-mediated transcription is dependent on the activation of NMDA receptors. Cortical neurons $\left(3 \times 10^{6}\right.$ cells/plate $)$ were transfected with the wild-type c-fos SRE-containing construct pAF42. SRE.wt $(1 \mu \mathrm{g} /$ plate) at 3 DIV. Three days later, cells were left untreated $(-)$, treated with $10 \mu \mathrm{M}$ glutamate in the absence or presence of $100 \mu \mathrm{M}$ APV, or treated with $100 \mu \mathrm{M}$ NMDA. RNase protection analysis was used to measure the expression of the transfected human c-fos gene (fos ${ }^{\mathrm{h}}$ ), the human $\alpha$-globin gene, and the endogenous rat c-fos gene (fos $\left.{ }^{\mathrm{r}}\right)$. $B$, Effects of mutations within the SRE that interfere with the binding of SRF or TCFs on SRE-mediated transcription. Cortical neurons $\left(3 \times 10^{6}\right.$ cells/plate) were transfected with $1 \mu \mathrm{g}$ of pAF42.SRE.wt, or constructs with mutations in the SRE that disrupt SRF binding (pAF42.SRE.pm1 or pAF42.SRE.mut2), or TCF binding (pAF42.SRE.mut6). Three days later, the transfected cells were either left untreated (-) or stimulated with $10 \mu \mathrm{M}$ glutamate. Similar results were obtained from three independent experiments. The relative levels of transcription between different reporter constructs after glutamate treatment were determined by the ratio of fos ${ }^{\mathrm{h}} /$ globin.

pAF42 (which lacks the SRE) was unresponsive to glutamate (data not shown). Transcription from the pAF42.SRE.wt reporter was efficiently induced by glutamate, however, and this transcriptional response was abolished by APV treatment (Fig. 4A). NMDA, an agonist specific for the NMDA receptor, also induced transcription from the pAF42.SRE.wt reporter but not pAF42. Together, these data suggest that NMDA-receptor activation can trigger SRE-dependent transcription in cortical neurons. In contrast to the wild-type SRE reporter, mutations that disrupt the binding of SRF to the SRE (SRE.pm1 or SRE.mut2) (Rivera et al., 1990; Misra et al., 1994) abolished glutamate induction of transcription through the SRE (Fig. $4 B$ ). When the binding site for TCFs was mutated (SRE.mut6) (Misra et al., 1994), the induction of transcription was $36 \%$ of that of the wild-type SRE after correcting for variations in transfection efficiency (Fig. 4B); similar results were seen in three independent experiments. $\mathrm{Mu}-$ tation of the TCF binding site has been shown previously not to interfere with SRF binding to the SRE (Misra et al., 1994). Taken together, these findings suggest that the binding site for SRF or an SRF-like factor is obligatory for SRE-mediated transcription and that the binding site for TCFs is required for a full transcriptional response to glutamate.

\section{Expression of recombinant SRF and Elk-1 can activate SRE-mediated transcription on glutamate stimulation}

The results described above suggest that the binding sites for SRF and TCFs are required for full SRE-mediated transcriptional activation in response to glutamate. To identify the specific transcription factors that can mediate glutamate induction of SREdependent transcription, we examined the possible roles of SRF and one of the TCF family members, Elk-1, in this process. We used an altered binding-specificity assay that allows the evaluation of the function of transfected SRF and Elk-1 without interference from their endogenous counterparts (Hill et al., 1993; Miranti et al., 1995). The pAF42.SRE.wt reporter construct was mutagenized to generate pAF42.SRE. $\mathrm{M}_{2}$, a construct in which the DNA binding site for SRF in the SRE (the CaRG box) was replaced with that of the yeast SRF homolog MCM-1 (Fig. 5). Endogenous wild-type SRF does not recognize the altered SRE $\left(\mathrm{SRE} . \mathrm{M}_{2}\right.$ ). A cotransfected mutant SRF (SRF.M2) can bind to SRE. $\mathrm{M}_{2}$, however, because it contains the DNA binding domain of MCM-1 in place of the DNA binding domain of the wild-type SRF. To evaluate the role of Elk-1 in SRE-dependent transcription, a mutation was introduced into pAF42.SRE. $\mathrm{M}_{2}$ to generate pAF42.SRE.LM ${ }_{2}$. In pAF42.SRE.LM ${ }_{2}$, the DNA binding site for 
A
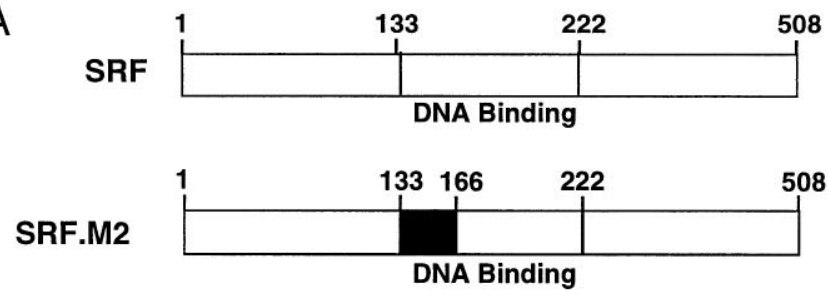

C

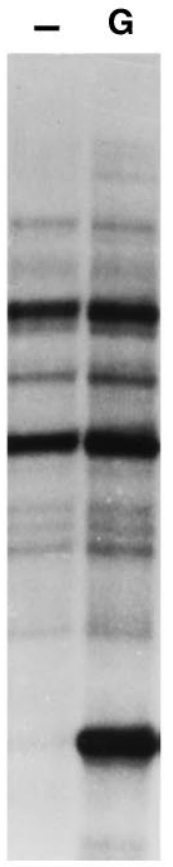

Reporter:

Activator:
SRE.M2

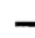

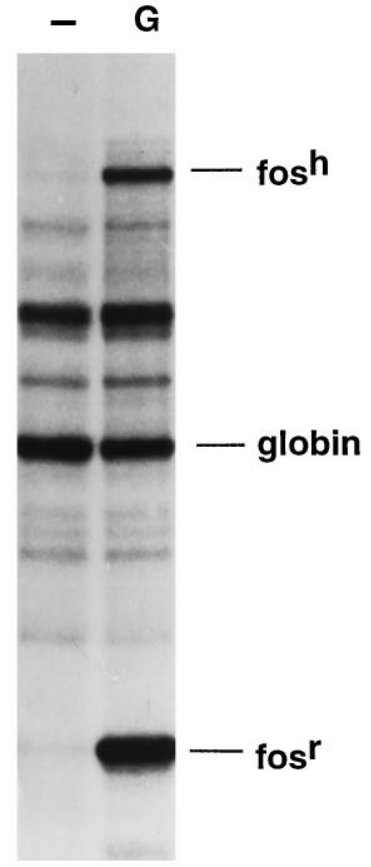

SRE.M2

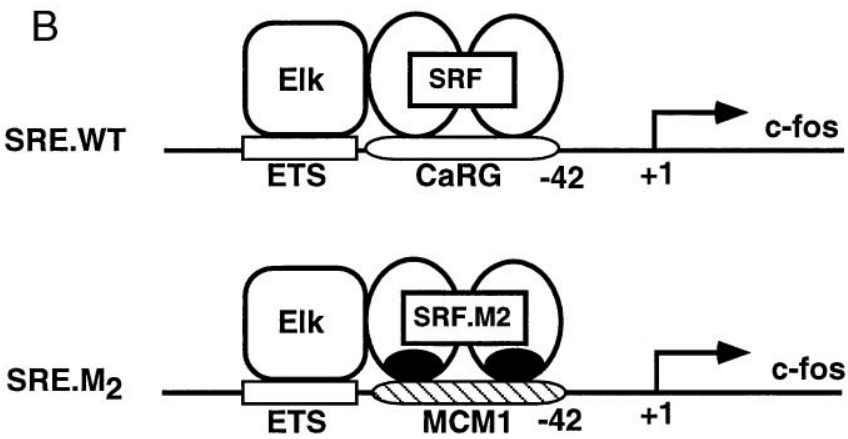

\section{SRF.M2}

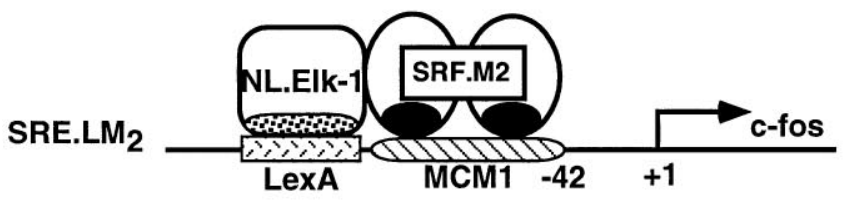

Figure 5. Ectopically expressed SRF can mediate SRE-dependent transcription stimulated by glutamate. $A$, Expression vectors used in the altered binding specificity assay (Hill et al., 1993). Amino acids 133-166 of the DNA binding domain of SRF were replaced with 33 amino acids from the DNA binding domain of MCM1 (black box) to create SRF.M2. Amino acids 3-87 of the LexA DNA binding domain (dotted box) were fused in-frame in front of amino acid 107 of Elk-1, which eliminates the Elk-1 DNA binding domain, to generate LexA-Elk. Ten additional amino acids encoding a nuclear localization signal (crossed box) were added to the $\mathrm{N}$ terminus of LexA-Elk to ensure its nuclear localization (NL.Elk-1). B, Reporter constructs used in the altered binding specificity assay (Hill et al., 1993; Miranti et al., 1995). Endogenous SRF binds as a homodimer to the CArG box of the wild-type SRE (pAF42.SRE.wt). TCFs, e.g., Elk-1, bind as a monomer to an ETS sequence adjacent to the CArG box only when SRF is already bound to the SRE. The CArG site was replaced by an MCM1 promoter sequence to generate pAF42.SRE.M ${ }_{2}$, which can bind SRF.M2 but not wild-type endogenous SRF. Endogenous Elk-like proteins can still bind to the ETS site in the SRE.M2. Additional substitution of the ETS site with a LexA site generated

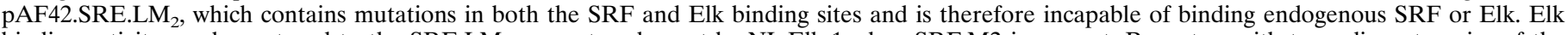
binding activity can be restored to the SRE.LM 2 promoter element by NL.Elk-1 when SRF.M2 is present. Reporters with two adjacent copies of the mutated SREs were used. $C, \mathrm{SRF}$ can mediate SRE-dependent transcription in response to glutamate. Cortical neurons were transfected with the reporter construct pAF42.SRE.M2 either alone or together with an expression vector encoding SRF.M2. Three days later, cells were either left untreated (-) or treated with $10 \mu \mathrm{M}$ glutamate. The level of mRNA transcribed from the reporter plasmid was assessed as described in the legend to Figure 4. Similar results were obtained from three independent experiments.

TCFs (the ETS site) was substituted with a site that binds the bacterial transcription factor LexA. Therefore, pAF42.SRE.LM 2 contains mutations in both the SRF and TCF binding sites and is incapable of binding to endogenous SRF or TCFs. A cotransfected modified version of Elk-1 (NL.Elk-1), in which the DNA binding domain of Elk-1 is replaced with that of LexA, can interact with SRE.LM ${ }_{2}$ but only when SRF.M2 is also bound.

When transfected into cortical neurons, pAF42.SRE.M 2 was completely unresponsive to glutamate stimulation (Fig. $5 C$ ), con- sistent with the inability of endogenous SRF to bind to SRE.M . $_{2}$ Glutamate induction of transcription from pAF42.SRE. $\mathrm{M}_{2}$ was restored when the expression vector SRF.M2 was cointroduced into neurons. The reporter plasmid pAF42.SRE.LM ${ }_{2}$, which can bind neither the endogenous SRF nor TCFs, was also unresponsive to glutamate stimulation (Fig. 6). Expression of the SRF.M2 protein, however, allowed glutamate induction of transcription from the pAF42.SRE.LM 2 . Coexpression of NL.Elk-1 reproducibly increased the level of transcription induced by glutamate by 
Figure 6. Glutamate stimulates SRE-mediated transcription through an Elk-dependent pathway. Cortical neurons $\left(3 \times 10^{6}\right.$ cells/plate $)$ were transfected with the c-fos reporter pAF42.SRE.LM ${ }_{2}(1 \mu \mathrm{g})$ together with $200 \mathrm{ng}$ of various expression plasmids as indicated: SRF.M2, NL.Elk-1, or NL.Elk-1(383/389). NL.Elk-1(383/389) contains alanine substitutions at $\mathrm{Ser}^{383}$ and $\mathrm{Ser}^{389}$, two of the MAP kinase phosphorylation sites in the $\mathrm{C}$ terminus of Elk-1. Three days after transfection, cells were either left untreated $(-)$ or treated with 10 $\mu \mathrm{M}$ glutamate. The level of mRNA transcribed from the reporter plasmid was assessed and quantitated as described in the legend for Figure 4. Relative levels of transcription from the reporter pAF42.SRE.LM ${ }_{2}$ after glutamate stimulation are SRF.M2, 100\%; SRF.M2 + NL.Elk-1, $154 \pm 5 \%$ (SEM, $n=5$ ); SRF.M2 + NL.Elk-1(383/389), $104 \pm 12 \%$ (SEM, $n=3)$.

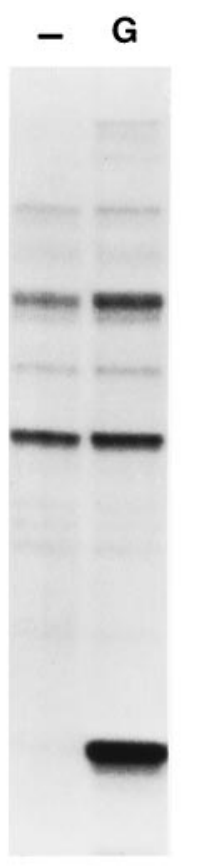

\section{Reporter: Activator: \\ SRE.LM2

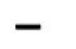

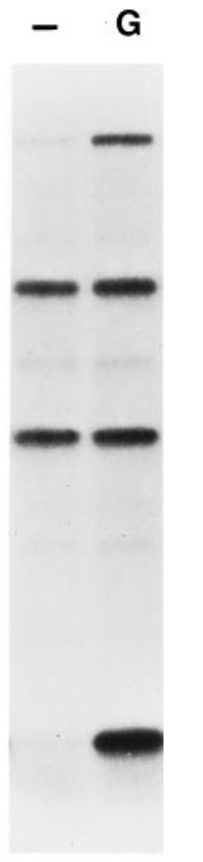

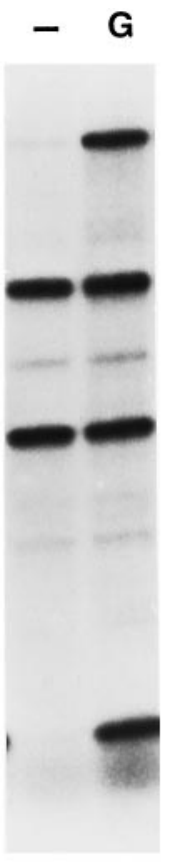

SRE.LM2 SRF.M2 NL.Elk-1

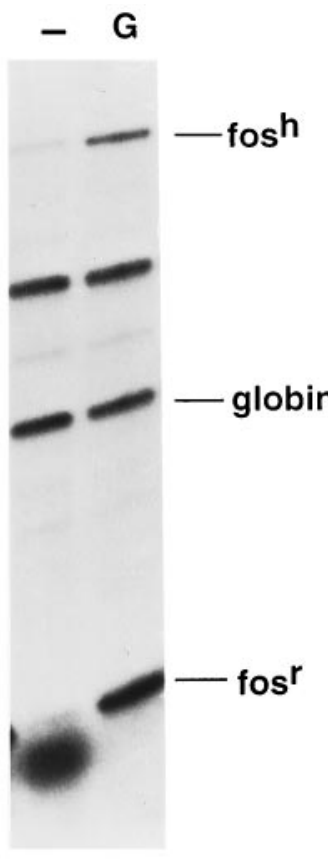

SRE.LM2

SRF.M2

NL.Elk-1 (383/389)
$50 \%$. These data suggest that both SRF and Elk-1 can contribute to SRE-dependent transcription in response to glutamate. There are apparently two pathways by which glutamate can activate transcription through the SRE: an SRF-dependent but Elkindependent pathway, because expression of SRF.M2 alone can mediate a significant level of transcription from the pAF42.SRE.LM ${ }_{2}$ reporter, and an Elk-dependent pathway, because addition of NL.Elk-1 further enhances transcription.

\section{Activation of ERKs mediates glutamate signaling to the SRE}

Phosphorylation of Elk-1 at residues $\mathrm{Ser}^{383}$ and $\mathrm{Ser}^{389}$ is crucial for Elk-1 to activate transcription (Hill et al., 1993; Marais et al., 1993; Janknecht et al., 1994; Miranti et al., 1995). Previous studies have shown that ERKs can directly phosphorylate Elk-1 at these residues in vitro. Furthermore, studies in fibroblasts and PC12 cells have demonstrated a close correlation between activation of the ERKs and the subsequent phosphorylation of Elk-1. These studies have suggested that activation of ERKs plays a critical role in regulating Elk-mediated gene expression in these cells. Although glutamate stimulation also activates ERKs in hippocampal (Bading and Greenberg, 1991) and cortical neurons (Fiore et al., 1993a,b) (L. Rosen, S. Finkbeiner, and M. E. Greenberg, unpublished observations), the function of ERKs in glutamate signaling in neurons has not been known. To examine whether phosphorylation of Elk-1 in response to glutamate regulates the ability of Elk to activate transcription, we tested whether a mutant Elk-1 in which the two regulatory serine residues $\operatorname{Ser}^{383}$ and $\operatorname{Ser}^{389}$ were replaced by alanines [NL.Elk-1(383/389)] enhanced transcription from pAF42.SRE.LM ${ }_{2}$. In contrast to results obtained using the wild-type protein NL.Elk-1, coexpression of NL.Elk-1(383/389) failed to further enhance the level of SRF.M2-mediated transcrip- tion initiated from pAF42.SRE.LM 2 (Fig. 6). This suggests that full transcriptional activation by glutamate through the SRE involves activation of a kinase, most likely an ERK, which catalyzes the phosphorylation of Elk-1 at serine residues $\operatorname{Ser}^{383}$ and $\operatorname{Ser}^{389}$.

To test further whether glutamate-stimulated ERKs regulate SRE-dependent transcription, we blocked ERK activation by introducing into cortical neurons a MAP kinase phosphatase, MKP-1, which is known to dephosphorylate and inactivate ERKs (Alessi et al., 1993; Sun et al., 1993, 1994). The ERKs are activated through a kinase cascade in which the kinase Raf phosphorylates and activates the dual specificity Thr-Tyr protein kinase MEK, which then phosphorylates and activates the ERKs (Cobb et al., 1991; Campbell et al., 1995). Constitutive expression of MKP-1 has been shown previously to lead to dephosphorylation of the ERKs, so that even in the presence of extracellular stimuli the ERKs are not activated effectively. Therefore, we tested the effect on glutamate induction of SRE-mediated transcription of cotransfecting an expression vector for MKP-1 along with expression vectors for SRF and Elk-1. As shown in Figure 7, compared to cotransfection with the empty vector pSG5 (top), coexpression of MKP-1 prevented NL.Elk-1 from further enhancing transcrip-

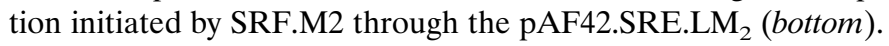
This result suggests that the ERKs, or a closely related kinase (Whitmarsh et al., 1995; Raingeaud et al., 1996), may play an important role in mediating Elk-dependent transcription in response to glutamate.

\section{DISCUSSION}

The objectives of this study were to identify transcription factors that activate transcription through the SRE in response to glutamate in neurons, and to characterize the signaling pathways that 


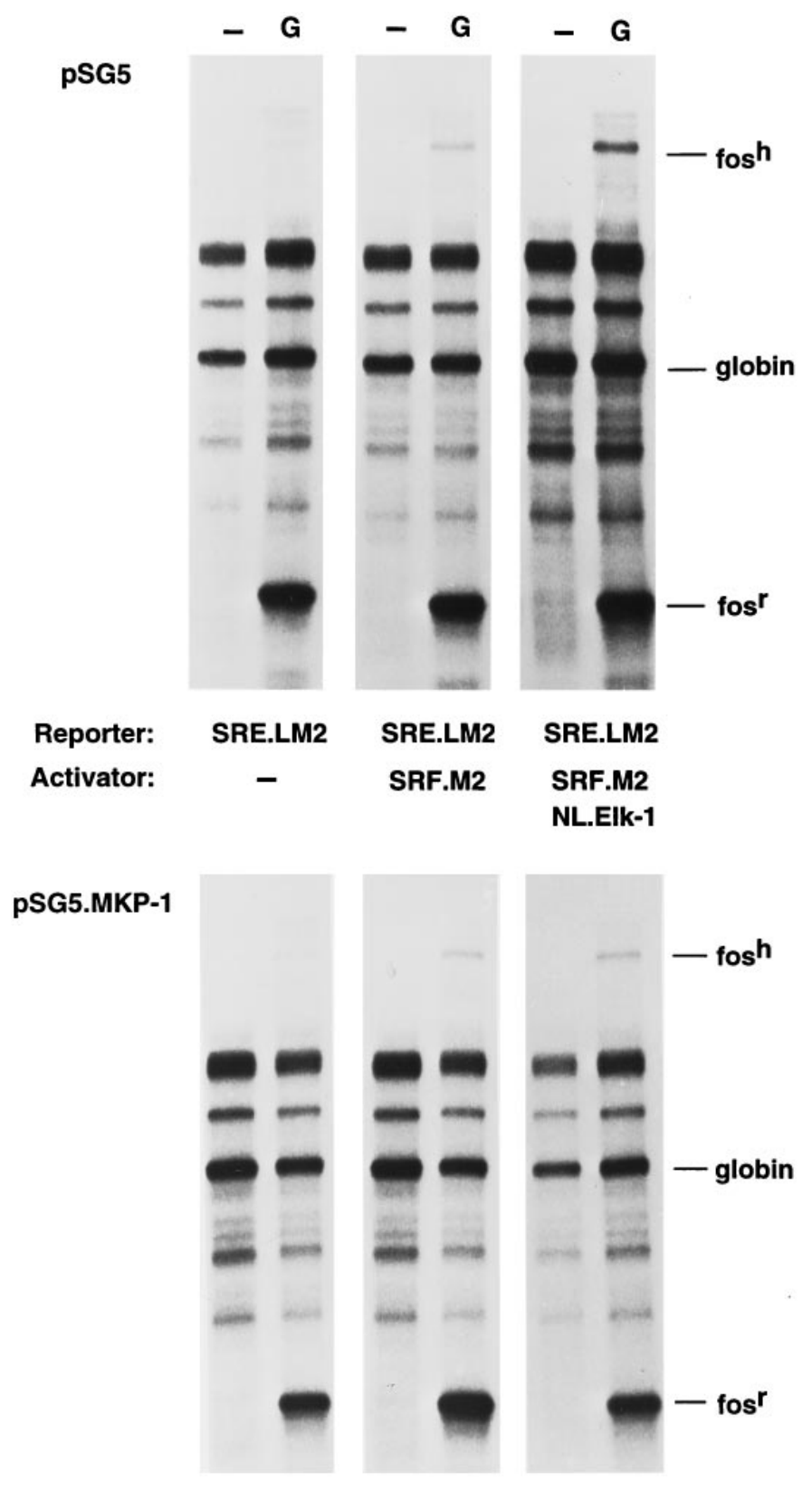

Figure 7. Coexpression of a MAP kinase phosphatase MKP-1 blocks Elk-dependent transcription. Cortical neurons were transfected with the c-fos reporter pAF42.SRE.LM ${ }_{2}$ alone or together with expression plasmids encoding SRF.M2 or NL.Elk-1, as indicated. Cells were also cotransfected with either the empty cloning vector pSG5 (top) or the expression vector pSG5.MKP-1 (bottom). Three days later, cells were either left untreated $(-)$ or treated with $10 \mu \mathrm{M}$ glutamate. The level of mRNA transcribed from the reporter plasmid was determined as described in the legend to Figure 4. In cells expressing MKP-1 (bottom), coexpression of Elk-1 failed to enhance transcription over that obtained with SRF alone, in comparison to cells transfected with vector alone (top). Similar results were obtained from two independent experiments.

lead to the activation of these transcription factors. To achieve these goals, we developed a reliable protocol for introducing DNA into neurons. We have used this method to transfect neurons cultured from hippocampus, cortex, striatum, spinal cord, and cerebellum (this study and data not shown). In addition to facilitating the study of gene regulation in neurons, this transfec- tion protocol should also be useful for studies of many other aspects of neuronal function. For example, it should be of use in characterizing the mechanisms controlling intracellular protein targeting and electrophysiological responses in neurons. We have recently applied this transfection method to identify at the single cell level signal transduction pathways involved in neuronal differentiation, survival, and death. For example, transfection of an expression vector encoding the apoptosis-inducing protein interleukin-1- $\beta$-converting enzyme caused $85 \%$ of transfected cortical neurons to undergo apoptosis (H. Dudek and M. E. Greenberg, unpublished observations).

In this report, we have demonstrated that glutamate induces c-fos transcription by an SRE-dependent mechanism in cortical neurons. Glutamate induction of SRE-dependent transcription seems to be mediated by the activation of NMDA receptors, because it is blocked by the NMDA-receptor antagonist APV. There are two distinct pathways by which glutamate activates SRE-mediated transcription. One pathway is SRF-dependent but Elk-independent, because the SRF binding site within the SRE is required for SRE-mediated transcription, and expression of SRF alone, in the absence of Elk, is sufficient to induce significant levels of transcription in response to glutamate. The second pathway is dependent on Elk, because the intact TCF binding site within the SRE is required for a full transcriptional response to glutamate stimulation, and coexpression of Elk-1 further enhances SRE-mediated transcription initiated by SRF.

The SRF-dependent but Elk-independent mechanism of glutamate-mediated transcriptional activation is not used by all extracellular stimuli that can induce c-fos. For example, in studies similar to those described here, we have discovered that brainderived neurotrophic factor stimulates SRE-dependent transcription in cortical neurons by a mechanism that is tightly dependent on the presence of both SRF and Elk (data not shown), as was reported previously for nerve growth factor (NGF) in PC12 cells (Misra et al., 1994; Bonni et al., 1995; Miranti et al., 1995). The SRF-dependent but Elk-independent pathway that we described here may serve as a major mechanism to induce transcription from those SRE-containing promoters that lack a functional TCF binding site. This pathway may also provide a mechanism for the regulation of those genes that are selectively induced by calcium but not neurotrophic factors (Vician et al., 1995).

Although previous work showed that ERKs are activated by glutamate stimulation, the physiological function of ERKs in glutamate signaling was unclear. In this report, we demonstrated that the two ERK phosphorylation sites at the $\mathrm{C}$ terminus of Elk-1, Ser ${ }^{383}$, and $\mathrm{Ser}^{389}$ are necessary for the ability of Elk to confer glutamate-induced transcription in neurons. In addition, coexpression of a phosphatase specific for the MAP kinase/ERKs, MKP-1, prevented Elk-1 from enhancing SRF-activated transcription through the SRE. Collectively, these results suggest that glutamate activation of the ERK signaling pathway is an important mechanism for Elk-1-dependent transcriptional activation. Whether other TCF family members, SAP-1 or SAP-2 for example, can mediate glutamate induction of transcription, and whether the ERK signaling pathway is important for the activation of such factors, remains to be determined. The fact that ERKs are found in neuronal cell bodies and dendrites (Fiore et al., 1993a,b), and once activated are believed to translocate to the nucleus (Chen et al., 1992; Gonzalez et al., 1993; Lenormand et al., 1993), provides supportive evidence for our proposal that ERKs transduce the glutamate signal from the cytoplasm to the nucleus where ERKs regulate gene expression by phosphorylating 
nuclear transcription factors such as Elk-1. Because glutamatestimulated gene expression may be important for synaptic plasticity and other synaptic functions, our results raise the possibility that SRF, Elk, and the MAP kinase/ERKs may play a role in these processes.

Several questions remain to be answered regarding mechanisms of glutamate-regulated transcription in neurons. For example, what are the signaling molecules that couple NMDA receptor activation to the ERKs and to SRE-mediated transcription? It will also be important to characterize the signaling pathways that mediate the SRF-dependent, Elk-independent activation of transcription by glutamate. Interestingly, glutamate treatment of neurons activates $\mathrm{Ca}^{2+}$ /calmodulin-dependent protein kinases (CaM kinases) (Hanson and Schulman, 1992; Bading et al., 1993; Schulman, 1993). In addition, calcium activates SRF-dependent transcription in PC12 cells by a CaM kinase signaling pathway (Miranti et al., 1995). It will be worthwhile to examine whether a CaM kinase is also involved in glutamate regulation of SRFdependent transcription in neurons. Furthermore, the Rho family of small GTP binding proteins RhoA, Rac1, and CDC42 have been implicated in regulating transcriptional activation by SRF in fibroblasts (Hill et al., 1995); whether these proteins play a role in glutamate signaling in neurons still needs to be examined.

Another important question that requires further study is how individual transcription factors function in the context of the full c-fos promoter. Studies using transgenic mice demonstrated that regulation of c-fos expression in many tissues requires the cooperative action of multiple transcription control elements (Robertson et al., 1995). In addition, in transient transfection assays in PC12 cells, SRF was found to cooperate with CREB in inducing c-fos expression in response to NGF (Bonni et al., 1995). CREB phosphorylation at serine ${ }^{133}$ is induced when cortical neurons are exposed to glutamate (Fig. 3). It will be useful to determine the role that CREB plays in glutamate-regulated gene expression in neurons.

In summary, by using a modified calcium phosphate transfection method to study gene regulation in primary neurons, we have identified two pathways that couple NMDA-receptor activation to SRE-mediated c-fos transcription: an SRF-dependent but Elkindependent pathway and an Elk-dependent pathway. Activation of ERKs seems to transmit the glutamate signal to the nucleus by phosphorylating Elk-1 and initiating Elk-dependent transcription from the SRE. Taken together, these results provide a functional link between activation of ERKs and regulation of glutamateinduced neuronal gene expression. Because some glutamateregulated immediate early genes (IEGs) such as Zif268 and Krox 20 are also induced by LTP paradigms, and SREs are present within the promoters of these IEGs (Changelian et al., 1989; Chavrier et al., 1989; Christy and Nathans, 1989), the mechanisms described here for the regulation of c-fos SRE transcription may be used generally by neurons to regulate gene expression during LTP and other adaptive neuronal responses.

\section{REFERENCES}

Alessi DR, Smythe C, Keyse SM (1993) The human CL100 gene encodes a Tyr/Thr-protein phosphatase which potently and specifically inactivates MAP kinase and suppresses its activation by oncogenic ras in Xenopus oocyte extracts. Oncogene 8:2015-2020.

Bading H, Greenberg ME (1991) Stimulation of protein tyrosine phosphorylation by NMDA receptor activation. Science 253:912-914.

Bading H, Ginty DD, Greenberg ME (1993) Regulation of gene expression in hippocampal neurons by distinct calcium signaling pathways. Science 260:181-186.
Bean BP (1989) Classes of calcium channels in vertebrate cells. Annu Rev Physiol 51:367-384.

Bear MF, Malenka RC (1994) Synaptic plasticity: LTP and LTD. Curr Opin Neurobiol 4:389-399.

Bliss TVP, Lømo T (1973) Long-lasting potentiation of synaptic transmission in the dentate area of the anaesthetized rabbit following stimulation of the perforant path. J Physiol (Lond) 232:331-356.

Bliss TVP, Collingridge GL (1993) A synaptic model of memory: longterm potentiation in the hippocampus. Nature 361:31-39.

Blochl A, Thoenen H (1995) Characterization of nerve growth factor (NGF) release from hippocampal neurons: evidence for a constitutive and an unconventional sodium-dependent regulated pathway. Eur J Neurosci 7:1220-1228.

Bonni A, Ginty DD, Dudek H, Greenberg ME (1995) Serine 133phosphorylated CREB induces transcription via a cooperative mechanism that may confer specificity to neurotrophin signals. Mol Cell Neurosci 6:168-183.

Campbell JS, Seger R, Graves JD, Graves LM, Jensen AM, Krebs EG (1995) The MAP kinase cascade. Recent Prog Horm Res 50:131-159. Changelian PS, Feng P, King TC, Milbrandt J (1989) Structure of the NGF-1A gene and detection of upstream sequence responsible for its transcriptional induction by nerve growth factor. Proc Natl Acad Sci USA 86:377-381.

Chavrier P, Janssen-Timmen U, Mattei M-G, Zerial P, Bravo R, Charnay P (1989) Structure, chromosomal location, and expression of the mouse zinc-finger gene Krox-20: multiple gene products and coregulation with the proto-oncogene c-fos. Mol Cell Biol 9:787-797.

Chen RH, Sarnecki C, Blenis J (1992) Nuclear localization and regulation of erk- and rsk-encoded protein kinases. Mol Cell Biol 12:915-927.

Cherrington JM, Mocarski ES (1989) Human cytomegalovirus iel transactivates the $\alpha$ promoter-enhancer via an 18-base-pair repeat element. J Virol 63:1435-1440.

Chomczynski P, Sacchi N (1987) Single-step method of RNA isolation by acid guanidinium thiocyanate-phenol-chloroform extraction. Anal Biochem 162:156-159.

Christy B, Nathans D (1989) Functional serum response elements upstream of the growth factor inducible zif268. Mol Cell Biol 9:4889-4895.

Cobb MH, Robbins DJ, Boulton TG (1991) ERKs, extracellular signalregulated MAP-2 kinases. Curr Opin Cell Biol 3:1025-1032.

Cole AJ, Saffen DW, Baraban JM, Worley PF (1989) Rapid increase of an immediate early gene messenger RNA in hippocampal neurons by synaptic NMDA receptor activation. Nature 340:474-475.

Dalton S, Treisman R (1992) Characterization of SAP-1, a protein recruited by serum response factor to the c-fos serum response element. Cell 68:597-612.

Deschamps J, Meijlink F, Verma IM (1985) Identification of a transcriptional enhancer element upstream from the proto-oncogene fos. Science 230:1174-1177.

Dragunow M, Abraham WC, Goulding M, Mason SE, Robertson HA, Faull RLM (1989) Long-term potentiation and the induction of c-fos mRNA and proteins in the dentate gyrus of unanesthetized rats. Neurosci Lett 101:274-280.

Fiore RS, Bayer VE, Posada PJ, Cooper JA, Baraban JM (1993a) p42 mitogen-activated protein kinase in brain: prominent localization in neuronal cell bodies and dendrites. Neuroscience 55:463-472.

Fiore RS, Murphy TH, Sanghera JS, Pelech SL, Baraban JM (1993b) Activation of p42 mitogen-activated protein kinase by glutamate receptor stimulation in rat primary cortical cultures. J Neurochem 61:1626-1633.

Fox K, Daw N, Sato H, Czepita D (1991) Dark-rearing delays the loss of NMDA-receptor function in kitten visual cortex. Nature 350:342-344.

Gabellini N, Minozzi M-C, Leon A, Toso RD (1992) Nerve growth factor transcriptional control of c-fos promoter transfected in cultured spinal sensory neurons. J Cell Biol 118:131-138.

Ghosh A, Greenberg ME (1995) Calcium signaling in neurons: molecular mechanisms and cellular consequences. Science 268:239-247.

Gille R, Sharrocks AD, Shaw PE (1992) Phosphorylation of transcription factor p62 $2^{\mathrm{TCF}}$ by MAP kinase stimulates ternary complex formation at the c-fos promoter. Nature 358:414-417.

Gille R, Kortenjann M, Thomae O, Moomaw C, Slaughter C, Cobb MH, Shaw PE (1995) ERK phosphorylation potentiates Elk-1-mediated ternary complex formation and transactivation. EMBO J 14:951-962. 
Gilman MZ, Wilson RN, Weinberg RA (1986) Multiple protein binding sites in the $5^{\prime}$-flanking region regulate c-fos expression. Mol Cell Biol 6:4305-4315.

Ginty DD, Bading H, Greenberg ME (1992) Trans-synaptic regulation of gene expression. Curr Opin Neurobiol 2:312-316.

Ginty DD, Kornhauser JM, Thompson MA, Bading H, Mayo KE, Takahashi JS, Greenberg ME (1993) Regulation of CREB phosphorylation in the suprachiasmatic nucleus by light and a circadian clock. Science 260:238-241.

Giovane A, Pintzas A, Maira S-M, Sobieszczuk P, Wasylyk B (1994) Net, a new ets transcription factor that is activated by Ras. Genes Dev 8:1502-1513.

Gonzalez FA, Seth A, Raden DL, Bowman DS, Fay FS, Davis RJ (1993) Serum-induced translocation of mitogen activated protein kinase to the cell surface ruffling membrane and the nucleus. $J$ Cell Biol 122:1089-1101.

Grant SG, O’Dell TJ, Karl KA, Stein PL, Soriano P, Kandel ER (1992) Impaired long-term potentiation, spatial learning, and hippocampal development in fyn mutant mice. Science 258:1903-1910.

Grecksch G, Matthies H (1980) Two sensitive periods for the amnesic effect of anisomycin. Pharmacol Biochem Behav 12:663-665.

Greenberg ME, Siegfried Z, Ziff EB (1987) Mutation of the c-fos gene dyad symmetry element inhibits serum inducibility of transcription in vivo and the nuclear regulatory factor binding in vitro. Mol Cell Biol 7:1217-1225

Hanson PI, Schulman H (1992) Neuronal $\mathrm{Ca}^{+2} /$ calmodulin-dependent protein kinases. Annu Rev Biochem 61:559-601.

Hill CS, Marais R, John S, Wynne J, Dalton S, Treisman R (1993) Functional analysis of a growth factor-responsive transcription factor complex. Cell 73:395-406.

Hill CS, Wynne J, Treisman R (1995) The Rho family GTPases RhoA, Rac1, and CDC42Hs regulate transcriptional activation by SRF. Cell 81:1159-1170.

Hipskind RA, Rao VN, Mueller CG, Reddy ESP, Nordheim A (1991) Ets-related protein Elk-1 is homologous to the c-fos regulatory factor p62 ${ }^{\text {TCF }}$. Nature 354:531-534.

Hipskind RA, Büscher D, Nordheim A, Baccarini M (1994) Ras/MAP kinase-dependent and -independent signaling pathways target distinct ternary complex factors. Genes Dev 8:1803-1816.

Huang YY, Li XC, Kandel ER (1994) cAMP contributes to mossy fiber LTP by initiating both a covalently mediated early phase and macromolecular synthesis-dependent late phase. Cell 79:69-79.

Jahr CE, Lester AJ (1992) Synaptic excitation mediated by glutamategated ion channels. Curr Opinion Neurobiol 2:270-274.

Janknecht R, Ernst WH, Pingoud V, Nordheim A (1993) Activation of ternary complex factor Elk-1 by MAP kinase. EMBO J 12:5097-5104.

Janknecht R, Zinck R, Ernst WH, Nordheim A (1994) Functional dissection of the transcription factor Elk-1. Oncogene 9:1273-1278

Jeffery KJ, Abraham WC, Dragunow M, Mason SE (1990) Induction of Fos-like immunoreactivity and the maintenance of long-term potentiation in the dentate gyrus of unanesthetized rats. Mol Brain Res $8: 267-274$

Kirkwood A, Dudek SM, Gold JT, Aizenman CD, Bear MF (1993) Common forms of synaptic plasticity in the hippocampus and neocortex in vitro. Science 260:1518-1521.

Kirkwood A, Lee HK, Bear MF (1995) Co-regulation of long-term potentiation and experience-dependent synaptic plasticity in visual cortex by age and experience. Nature 375:328-331.

Kleinschmidt A, Bear MF, Singer W (1987) Blockade of "NMDA" receptors disrupts experience-dependent plasticity of kitten striate cortex. Science 238:355-358.

Korner M, Rattner A, Mauxion F, Sen R, Citri Y (1989) A brain specific transcription activator. Neuron 3:563-572.

Lenormand P, Sardet C, Pages G, L'Allemain G, Brunet A, Pouyssegur J (1993) Growth factors induce nuclear translocation of MAP kinases (p42 $2^{\text {mapk }}$ and $\mathrm{p} 44^{\mathrm{mapk}}$ ) but not of their activator MAP kinase kinase (p56 ${ }^{\text {mapkk }}$ ) in fibroblasts. J Cell Biol 122:1079-1088.

Lerea LS, McNamara JO (1993) Ionotropic glutamate receptor subtypes activate c-fos transcription by distinct calcium-requiring intracellular signaling pathways. Neuron 10:31-41.

Madison DV, Malenka RC, Nicoll RA (1991) Mechanisms underlying long term potentiation of synaptic transmission. Annu Rev Neurosci 14:379-397.

Malenka RC (1994) Synaptic plasticity in the hippocampus: LTP and LTD. Cell 78:535-538.
Marais R, Wynne J, Treisman R (1993) The SRF accessory protein Elk-1 contains a growth factor-regulated transcriptional activation domain. Cell 73:381-393.

Mathies H, Frey U, Reymann K, Krug M, Jork R, Schroeder H (1990) Different mechanisms and multiple stages of LTP. Adv Exp Med Biol 268:359-368.

Miranti CK, Ginty DD, Huang G, Chatila T, Greenberg ME (1995) Calcium activates serum response factor-dependent transcription by a Ras- and Elk-1-independent mechanism that involves a $\mathrm{Ca}^{2+}$ / calmodulin-dependent kinase. Mol Cell Biol 15:3672-3684.

Misra RP, Bonni A, Miranti CK, Rivera VM, Sheng M, Greenberg ME (1994) Calcium entry through L-type voltage sensitive calcium channels can activate transcription via the serum response factor. J Biol Chem 269:25483-25493.

Montarolo PG, Geolet P, Castellucci VF, Morgan J, Kandel ER (1986) A critical period for macromolecular synthesis in long-term heterosynaptic facilitation in Aplysia. Science 234:1249-1254.

Mueller CGF, Nordheim A (1991) A protein domain conserved between yeast MCM1 and human SRF directs ternary complex formation. EMBO J 10:4219-4229.

Nakanishi S (1992) Molecular diversity of glutamate receptors and implications for brain function. Science 258:597-603.

Nguyen PV, Abel T, Kandel ER (1994) Requirement of a critical period of transcription for induction of a late phase of LTP. Science 265:1104-1107.

Norman C, Runswick M, Pollock R, Treisman R (1988) Isolation and properties of cDNA clones encoding SRF, a transcription factor that binds to the c-fos serum response element. Cell 55:989-1003.

Price MA, Rogers AE, Treisman R (1995) Comparative analysis of the ternary complex factors Elk-1, SAP-1a and SAP-2(ERP/NET). EMBO J 14:2589-2601.

Prywes R, Roeder RG (1986) Inducible binding of a factor to the c-fos enhancer. Cell 47:777-784.

Rabacchi S, Bailly Y, Delhaye-Bouchaud N, Mariani J (1992) Involvement of the NMDA receptor in synapse elimination during cerebellar development. Science 256:1823-1825.

Raingeaud J, Whitmarsh AJ, Barrett T, Dérijard B, Davis RJ (1996) MKK3- and MKK6-regulated gene expression is mediated by the p38 mitogen-activated protein kinase signal transduction pathway. Mol Cell Biol 16:1247-1255.

Rao VN, Huebner K, Isobe M, AR-Rushdie A, Croce CM, Reddy ES (1989) elk, tissue-specific ets-related genes on chromosomes $\mathrm{X}$ and 14 near translocation breakpoints. Science 244:66-70.

Rivera VM, Greenberg ME (1990) Growth factor-induced gene expression: the ups and downs of c-fos regulation. New Biol 2:751-758.

Rivera VM, Sheng M, Greenberg ME (1990) The inner core of the serum response element mediates both the rapid induction and subsequent repression of c-fos transcription following serum stimulation. Genes Dev 4:255-268.

Robertson LM, Kerppola TK, Vendrell M, Luk D, Smeyne RJ, Bocchiaro C, Morgan JI, Curran T (1995) Regulation of c-fos expression in transgenic mice requires multiple interdependent transcription control elements. Neuron 14:241-252.

Schulman $\mathrm{H}$ (1993) The multifunctional $\mathrm{Ca}^{2+} /$ calmodulin-dependent protein kinases. Curr Opin Cell Biol 5:247-253.

Seeburg PH (1993) The molecular biology of mammalian glutamate receptor channels. Trends Neurosci 16:359-365.

Shaw PE (1992) Ternary complex formation over the c-fos serum response element: p62 $2^{\mathrm{TCF}}$ exhibits dual component specificity with contacts to DNA and an extended structure in the DNA-binding domain of p67 ${ }^{\text {SRF }}$. EMBO J 11:3011-3019.

Shaw PE, Shroter H, Nordheim A (1989) The ability of a ternary complex to form over the serum response element correlates with serum inducibility of the c-fos promoter. Cell 56:563-572.

Sheng M, Greenberg ME (1990) The regulation and function of c-fos and other immediate early genes in the nervous system. Neuron 4:477-485.

Sheng M, Dougan ST, McFadden G, Greenberg ME (1988) Calcium and growth factor pathways of c-fos transcriptional activation require distinct upstream regulatory sequences. Mol Cell Biol 8:2787-2796.

Shyu A-B, Greenberg ME, Belasco JG (1989) The c-fos transcript is targeted for rapid decay by two distinct mRNA degradation pathways. Genes Dev 3:60-72. 
Silva AJ, Stevens CF, Tonegawa S, Wang Y (1992) Deficient hippocampal long-term potentiation in $\alpha$-calcium-calmodulin kinase II mutant mice. Science 257:201-211.

Sun H, Charles CH, Lau LF, Tonks NK (1993) MKP-1 (3CH134), an immediate early gene product, is a dual specificity phosphatase that dephosphorylates MAP kinase in vivo. Cell 75:487-493.

Sun H, Tonks NK, Bar-Sagi D (1994) Inhibition of Ras-induced DNA synthesis by expression of the phosphatase MKP-1. Science 266:285-288.

Treisman R (1985) Transient accumulation of c-fos RNA following serum stimulation requires a conserved 5' element and c-fos $3^{\prime}$ sequences. Cell 42:567-574.

Treisman R (1986) Identification of a protein binding site that mediates transcriptional response of the c-fos gene to serum factors. Cell 46:567-574.

Treisman R (1992) The serum response element. Trends Biochem Sci 17:423-426.

Treisman R (1994) Ternary complex factors: growth factor regulated transcriptional activators. Curr Opinion Gen Dev 4:96-101.

Treisman R (1995) Journey to the surface of the cell: Fos regulation and the SRE. EMBO J 14:4905-4913.

Tsien RW, Lipscombe D, Madison DV, Bley KR, Fox AP (1988) Multiple types of neuronal calcium channels and their selective modulation. Trends Neurosci 11:431-437.

Vician L, Lim IK, Ferguson G, Tocco G, Baudry M, Herschman HR (1995) Synaptotagmin IV is an immediate early gene induced by depo- larization in PC12 cells and in brain. Proc Natl Acad Sci USA 92:2164-2168.

Werner M, Madreperla S, Lieberman P, Adler R (1990) Expression of transfected genes by differentiated, post-mitotic neurons and photoreceptors in primary cell cultures. J Neurosci Res 25:50-57.

Whitmarsh AJ, Shore P, Sharrocks AD, Davis RJ (1995) Integration of MAP kinase signal transduction pathways at the serum response element. Science 269:403-407.

Williams J, Dragunow M, Lawlor P, Mason S, Abraham WC, Leah J, Bravo R, Demmer J, Tate W (1995) Krox20 may play a key role in the stabilization of long-term potentiation. Brain Res Mol Brain Res 28:87-93.

Worley PF, Bhat RV, Baraban JM, Erickson CA, McNaughton BL, Barnes CA (1993) Thresholds for synaptic activation of transcription factors in hippocampus: correlation with long-term enhancement. J Neurosci 13:4776-4786.

Wu ZL, Thomas SA, Villacres EC, Xia Z, Simmons ML, Chavkin C, Palmiter RD, Storm DR (1995) Altered behavior and long-term potentiation in type I adenylyl cyclase mutant mice. Proc Natl Acad Sci USA 92:220-224.

Yin JCP, Wallach JS, Del Vecchio M, Wilder EL, Zhou H, Quinn WG, Tully $T$ (1994) Induction of a dominant negative CREB transgene specifically blocks long-term memory in Drosophila. Cell 79:49-58. 